\title{
Applications of Proteolytic Enzymes from Kiwifruit on Quality Improvements of Meat Foods in Foodservice
}

\author{
Kyung-A Lee, Sook-Hee Jung ${ }^{1}$, and Inshik Park ${ }^{1 *}$ \\ Research Institute Human Ecology, Dong-A University, Busan 604-714, Korea \\ ${ }^{1}$ Department of Food and Nutrition, Dong-A University, Busan 604-714, Korea
}

\begin{abstract}
The purpose of this study was to evaluate kiwifruit as a tenderizer by its effects in improving the quality of various beef parts. Basic data are provided for development of standard recipes for convenient cooking in foodservice. The optimum temperature of the crude proteolytic enzymes in the kiwifruit was determined to be $65^{\circ} \mathrm{C}$. The substrate specificity of the enzymes was higher in beef than in pork, chicken, or duck. The enzymes had their greatest effects on chuck and rib parts, and had lower effects on loin, breast, and round parts, in that order. As the amount of kiwifruit extract increased, the moisture content of the cooked beef also increased. The addition of $10 \%$ kiwifruit improved the sensory quality of the cooked beef. In particular, the texture scores of cooked beef samples treated with $10 \%$ and $15 \%$ kiwifruit extract were significantly higher than the other samples $(p<0.001)$, and juiciness and overall acceptability scores were also highest. In summary, $10 \%$ kiwifruit extract is deemed an appropriate addition to improve.
\end{abstract}

Key words: kiwifruit, proteolytic enzyme, beef, tenderness, foodservice

\section{Introduction}

School foodservice provides nutritionally balanced meals, enables students to have appropriate eating habits, and resolves unbalanced diets in students. Therefore, students can be healthy, aiding increases in academic efficiency and an inspired community spirit (Kwak et al., 2007). In 2009, among all elementary, middle, high, and special schools in Korea, 99.9\%, or 11,303 of them, had school lunch programs, and $98.5 \%$ of all students $(7.3$ million) were therefore affected (Ministry of Education, Science and Technology, 2010).

With increases in national income and dietary lifestyle changes from grains to dairy products, demands for meat and meat products are increasing in foodservice. According to Kim et al. (2006) who performed research on preferences toward school lunch program menus in high school students in Daegu, the students preferred meat foods prepared by steaming, braising, stir frying, grilling, and deep frying. In addition, boys seemed to prefer meat more than girls. According to Park and Kim (2008), in middle school foodservice, meat was the most liked

*Corresponding author: Inshik Park, Department of Food and Nutrition, Dong-A University, Busan 604-714, Korea. Tel: 8251-200-7322, Fax: 82-51-200-7535, E-mail: ispark@dau.ac.kr ingredient by $39.8 \%$. But what students wanted school authorities to do most was to improve the taste of school foodservice menu items (Lee and Park, 2010). Girls tended not to eat meat dishes because they didn't like their taste (Oh et al., 2006). Thus, improvements in ingredient quality and cooking technology are urgently needed.

People tend to prefer meat more than any other food (Kim et al., 2006; Kim, 2008; Yoon and Woo, 1999), but preferences differ according to the kind of meat (Jang and Kim, 2009; Kim et al., 2009; Lee et al., 2009) and cooking method (Kim et al., 2009; Park and Park, 2001). Lawrie and Leward (2006) proposed that appearance, juiciness, tenderness, and flavor are important factors in judging the quality of beef. Calkins and Hodgens (2007) mentioned that fat content affects juiciness and flavor in a good way. Tenderness is the most important factor in overall acceptability (Destefanis et al., 2008), and tenderness, juiciness, and flavor affect overall acceptability in the respective order, (Serra et al., 2008). The Gyeonggi Provincial government (2010) is making efforts to raise student satisfaction of foodservice by providing first-rate Hanwoo. However, students prefer soft meat parts such as the sirloin, tenderloin, and ribs over tougher parts such as the chuck, round, foreshank, and brisket. In order to utilize the tougher parts and provide preferred meat menus, it is very important to develop food preparation tech- 
niques appropriate for mass cooking that can enhance tenderness and water-holding capacity.

Koreans have used pear (Choe and Park, 1996; Han and Chin, 2004), ginger (Kim and Lee, 1995), paper mulberry (Yun and Jang, 1997), and bark (Park and Kwon, 1998; Kwon et al. 1998) to tenderize meat. It was reported that the proteolytic activity of pears is much lower than that of tropical fruits such as pineapple, kiwifruit, and papaya (Bai and Roh, 2000). Thus, much research (Cho et al., 1994; Kim et al., 2003; Kim et al., 2009; Lee et al., 2009; Oh et al., 2002) has been performed on using proteolytic enzymes from tropical fruits like pineapple and kiwifruit as meat tenderizers. However, at home or in foodservice, food preparation using fruit extracts is preferred (Bai and Roh, 2000). In order to prevent excessive decomposition due to the strong activity of proteolytic enzymes, the development of standard recipes is necessary.

The purpose of this study was to evaluate kiwifruit as a tenderizer in various beef part and to provide basic data for the development of standard recipes for convenient cooking in foodservice.

\section{Materials and Methods}

\section{Samples preparation}

Domestic kiwifuit (Actinidia chinensis), Hanwoo (Korean beef; chuck, loin, breast, rib, and round), domestic port (ham), and domestic chicken and duck (breast) were purchased from a local supermarket.

\section{Preparation of the crude proteolytic enzymes}

One-hundred grams of eatable kiwifruit parts were taken, squeezed, and centrifuged at $15,000 \mathrm{~g}$, for $20 \mathrm{~min}$ at $4^{\circ} \mathrm{C}$. The supernatant was used as the crude enzymes.

\section{Assay of proteolytic enzymes}

The activity of the proteolytic enzymes was measured by the following method. First, $0.5 \mathrm{~mL}$ of acetate buffer (pH 5.0) and $0.05 \mathrm{~mL}$ of crude enzymes were added to $0.5 \mathrm{~g}$ of beef chuck. Next, the meat was incubated at $37^{\circ} \mathrm{C}$ for $30 \mathrm{~min}$, After incubation, $0.5 \mathrm{~mL}$ of TCA was added followed by centrifugation at $1,000 \mathrm{rpm}$ for $5 \mathrm{~min}$. The supernatant was used in measurements. The products of enzymatic proteolysis were measured by Lowry's method (Low et al., 1951), and absorbance was measured by a spectrophotometer at $660 \mathrm{~nm}$. One unit of enzyme activity was defined as the activity of enzymes per $1.0 \mathrm{~mL}$ to increase absorbance 0.001 per min.

\section{Moisture content}

The moisture contents of the cooked meat samples were measured by AOAC (1995) methods with dehydration at $105^{\circ} \mathrm{C}$.

\section{Sensory properties}

The round muscle of the beef was sliced to $2.0 \mathrm{~cm}$ wide, $2.5 \mathrm{~cm}$ thick, and $0.3 \mathrm{~cm}$ long, and then it was seasoned. The seasoning was composed (w/w) of water $(10 \%)$, soy sauce $(5 \%)$, and kiwifruit extract $(5 \%, 10 \%$, $15 \%)$. After seasoning for $2 \mathrm{~h}$, the meat was broiled in an oven at $120^{\circ} \mathrm{C}$ for $3 \mathrm{~min}$. The control was seasoned with water and soy sauce only.

The sensory qualities of the broiled beef samples were evaluated by an experienced panel of 10 judges who were majors in food and nutrition. The samples of broiled beef were served on identical dishes to each panelist and all of them looked the same. Sensory profile analysis was used to describe taste, appearance, color, texture, juiciness, flavor, and overall acceptability. Sensory property evaluations were carried out using ratings from 1.0 (very weak) to 5.0 (very strong). The panelists tested each set of three sample three times.

\section{Statistical analysis}

The data were analyzed by ANOVA using the SAS statistical program, and significant differences among various treatments were compared using Duncan's multiple range tests (SAS Institute, Inc., Cary, NC, USA, 1996).

\section{Results and Discussion}

\section{Properties of proteolytic enzymes}

The effects of temperature on enzyme activity are shown in Fig. 1. As temperature increased, crude enzyme activity increased sharply until reaching $65^{\circ} \mathrm{C}$ and then it decreased rapidly. The enzyme activity at $65^{\circ} \mathrm{C}$ was 433.7 $\mathrm{mL} / \mathrm{mL}$, which was referred to $100 \%$ relativity activity. The enzyme activities at various temperatures were described as relativive activity (\%) compared to $65^{\circ} \mathrm{C}$ for easier comparison between temperature effect. Therefore, the optimum temperature of the crude proteolytic enzymes in the kiwifruit was determined as $65^{\circ} \mathrm{C}$. This result disagrees with reports by Bai and Roh (2000) and Cho et al. (1994), which claimed that the optimum temperature was $40^{\circ} \mathrm{C}$. However, our data were similar to results found by Yamaguchi et al. (1982), which indicated an optimum temperature of $58-62^{\circ} \mathrm{C}$. These differences in optimal temperature might be due to differences in the substrate 


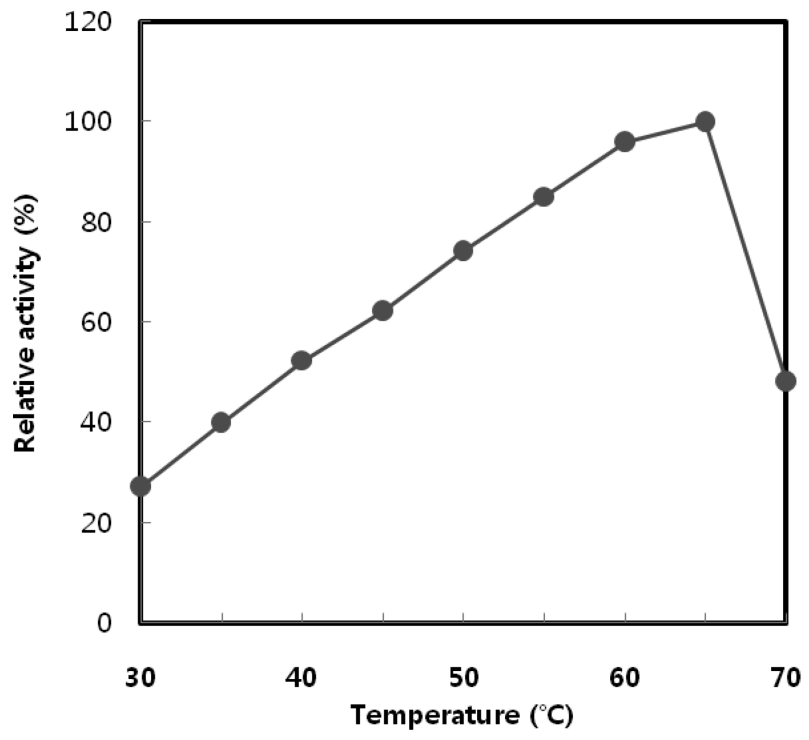

Fig. 1. Effects of temperature on the activity of proteolytic enzyme from kiwifruit. The enzyme activity at $65^{\circ} \mathrm{C}$ was 433.7 unit $/ \mathrm{mL}$ with beef as a substrate, which was referred to $100 \%$ relative activity.

used. The results of this study indicate that proteolytic enzymes from kiwifruit have tenderizing effects during heat processing.

\section{Substrate specificity}

The effects of the proteolytic enzymes on various kinds of meat foods (beef, pork, chicken, duck) are shown in Fig. 2. The enzyme activity with beef as a substrate was $228.5 \mathrm{unit} / \mathrm{mL}$ at $37^{\circ} \mathrm{C}$, which was referred to $100 \%$ relative activity, while relative enzyme activities with various

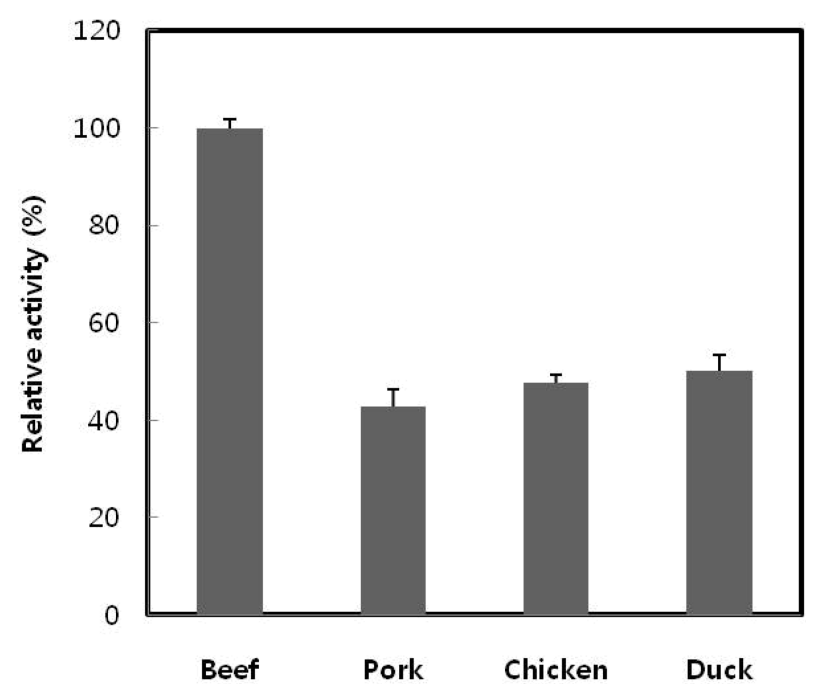

Fig. 2. Proteolysis of various meat foods by kiwifruit. The enzyme activity with beef as a substrate was 228.5 unit/ $\mathrm{mL}$ at $37^{\circ} \mathrm{C}$, which was referred to $100 \%$ relative activity. meats were described compared to enzyme activity with beef as a substrate. The enzymes had their greatest effects on beef, while they had lower effects on pork, chicken, and duck, but at similar levels. Therefore, the substrate specificity of the enzyme was relatively high in the beef. These results disagree with a report by Suh et al. (1998) where proteases from vegetables had greater effects on pork than on beef.

The effects of the proteolytic enzymes on various beef parts are shown in Fig. 3. The enzyme activity with beef chuck was referred to $100 \%$, while enzyme activities with various beef parts were described as relative activity (\%)

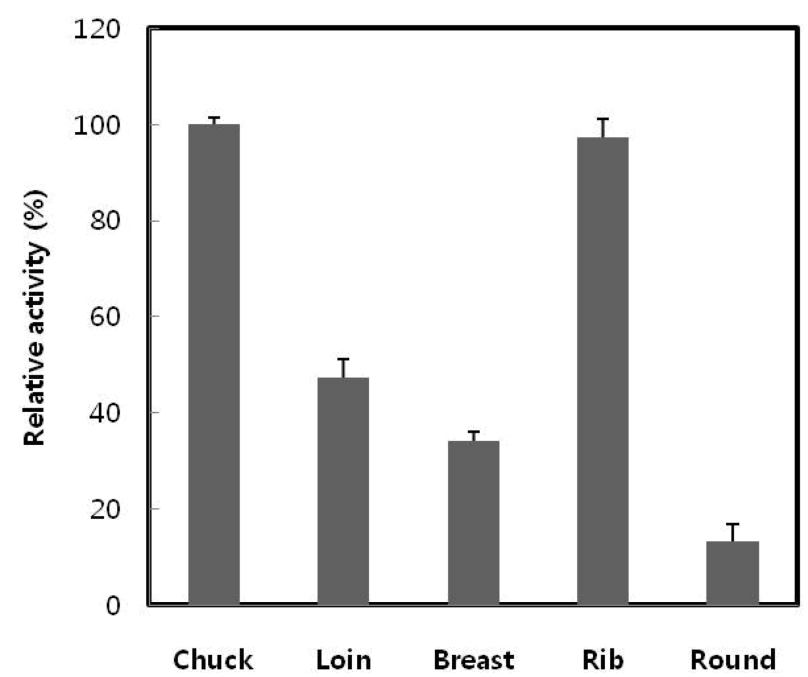

Fig. 3. Proteolysis of various beef parts by kiwifruit. The enzyme activity with a beef chuck as a substrate was $228.5 \mathrm{unit} / \mathrm{mL}$ at $37^{\circ} \mathrm{C}$, which was referred to $100 \%$ relativity activity.

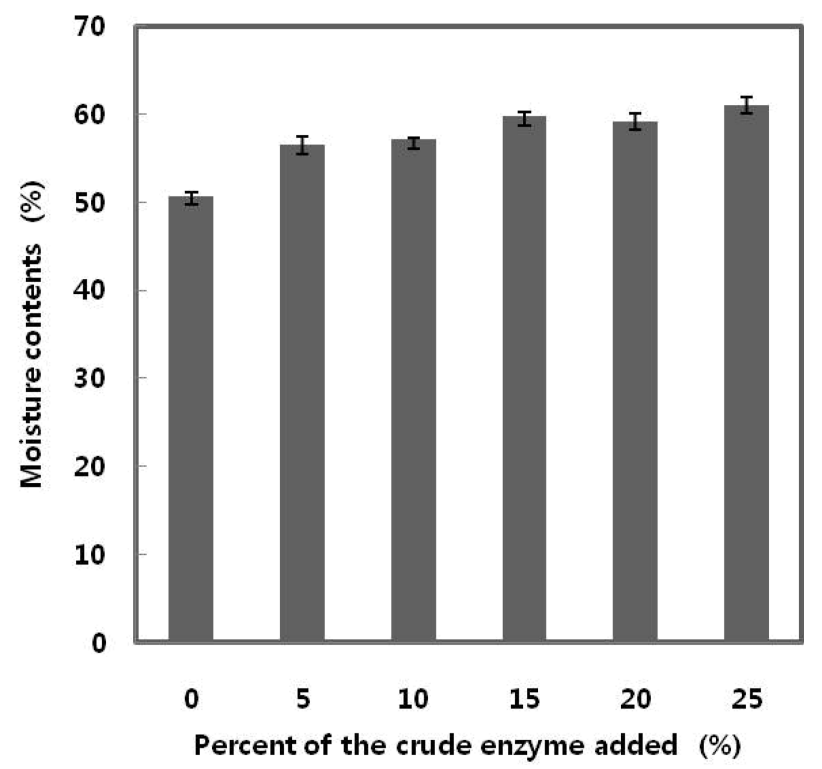

Fig. 4. Moisture contents of cooked beef samples made with different amounts of kiwifruit. 
Table 1. Sensory characteristics of cooked beef by different amounts of Kiwifruit

\begin{tabular}{llcccc}
\hline \hline \multirow{2}{*}{$\begin{array}{c}\text { Sensory } \\
\text { characteristics }\end{array}$} & \multicolumn{5}{c}{ Percent of the crude enzyme added (\%) } \\
\cline { 2 - 5 } & \multicolumn{1}{c}{0} & 5 & 10 & \multirow{2}{*}{ F-value } \\
\hline Taste & $3.40 \pm 0.69^{1) \mathrm{b} 2)}$ & $2.40 \pm 0.51^{\mathrm{a}}$ & $3.50 \pm 1.26^{\mathrm{b}}$ & $2.80 \pm 1.03^{\mathrm{ab}}$ & $3.13^{*}$ \\
Appearance & $3.00 \pm 0.94$ & $2.60 \pm 1.07$ & $3.50 \pm 1.26$ & $2.80 \pm 0.91$ & 1.32 \\
Color & $3.40 \pm 0.51^{\mathrm{b}}$ & $2.40 \pm 0.69^{\mathrm{a}}$ & $3.30 \pm 1.05^{\mathrm{b}}$ & $3.50 \pm 0.97^{\mathrm{b}}$ & $3.63^{*}$ \\
Texture & $1.90 \pm 0.73^{\mathrm{a}}$ & $2.20 \pm 0.63^{\mathrm{ab}}$ & $3.70 \pm 1.25^{\mathrm{c}}$ & $2.90 \pm 0.73^{\mathrm{b}}$ & $8.41^{* * *}$ \\
Juiciness & $2.60 \pm 0.84^{\mathrm{ab}}$ & $2.30 \pm 0.48^{\mathrm{a}}$ & $3.30 \pm 1.15^{\mathrm{b}}$ & $2.20 \pm 1.03^{\mathrm{a}}$ & $2.94^{*}$ \\
Flavor & $3.20 \pm 0.42^{\mathrm{ab}}$ & $2.30 \pm 0.67^{\mathrm{a}}$ & $3.60 \pm 1.26^{\mathrm{b}}$ & $3.00 \pm 1.24^{\mathrm{ab}}$ & $3.12^{*}$ \\
Overall acceptability & $3.50 \pm 0.70^{\mathrm{b}}$ & $2.30 \pm 0.94^{\mathrm{a}}$ & $3.60 \pm 1.17^{\mathrm{b}}$ & $3.00 \pm 1.24^{\mathrm{ab}}$ & $3.26^{*}$ \\
\hline
\end{tabular}

${ }^{1)}$ Mean \pm S.D ( $\left.\mathrm{n}=10\right)$.

${ }^{2)}$ Values with different letters within a column differ significantly $(p<0.05)$.

${ }^{*} p<0.05,{ }^{* * *} p<0.001$.

compared to enzyme activity with beef chck for better comparison. The enzymes had their greatest effect on the beef chuck, followed by rib, and had lower effects on the loin, breast, and round, in the respective order.

\section{Moisture contents}

The moisture contents of the cooked beef samples prepared using different amounts of kiwifruit extract are shown in Fig. 4. As the amount of kiwifruit increased, the moisture content of the broiled beef also increased. This is a similar to data reported by Lee et al. (2001). Proteolytic enzymes from kiwifruit hydrolyze beef proteins leading to increases in water-soluble substances. Such enzymes are thought to have caused the above results. However, Kim et al. (2003) reported that the water-holding capacity of low-grade ribs seasoned with kiwi powder decreased compared to a control as the amount of kiwi powder increased. The excessive activity of actinidin in kiwifruit causes excessive protein decomposition and increases drip loss, which is thought to cause the above results. These data indicate that appropriate amounts of proteolytic enzymes lead to increases in juiciness, but excessive amounts decrease juiciness.

\section{Sensory evaluation}

The sensory characteristics of the cooked beef samples made with different amounts of kiwifruit extract are shown in Table 1.

The sensory scores of the cooked beef samples made with $10 \%$ kiwifruit extract were highest for taste, appearance, texture, juiciness, flavor, and overall acceptability. Particularly for texture, the score of the cooked beef made with $10 \%$ kiwi (3.7) was significantly higher than that of the control (1.9) as well as the samples made with 5\% (2.3) and 15\% (2.9) extract $(p<0.001)$. For juiciness, the score of the cooked beef made with $10 \%$ kiwi (3.3) was significantly higher compared to beef samples made with $5 \%(2.3)$ and $15 \%(2.2)(p<0.05)$. The cooked beef prepared with $15 \%$ kiwi extract received low scores for texture (2.9) and juiciness (2.2); therefore, overall acceptability was also lower. These results agree with a report by Kim et al. (2003) where natural tenderizers such as kiwi and pear powder had tenderizing effects on lowgrade seasoned ribs, and overall acceptability was closely connected with tenderness and juiciness. To summarize, in order to improve the quality of broiled beef, $10 \%$ kiwifruit extract is deemed appropriate.

\section{Acknowledgement}

This work was supported by the Dong-A University research fund.

\section{References}

1. AOAC (2007) Official methods of analysis. 18th ed, Association of Official Analytical Chemists, Washington, DC, p. 931.

2. Bai, Y. H. and Roh, J. H. (2000) Application of proteolytic enzymes in fruits for meat tenderization. Korean J. Soc. Food Sci. 16, 367-371.

3. Bai, Y. H. and Roh, J. H. (2000) The properties of proteolytic enzymes in fruits (pear, kiwifruit, fig, pineapple, and papaya). Korean J. Soc. Food Sci. 16, 363-366.

4. Calkins, C. R. and Hodgen, J. M. (2007) A fresh look at meat flavour. Meat Sci. 77, 63-80.

5. Cho, S. J., Chung, S. H., Suh, H. J., Lee, H., Kong, D. H., and Yang, H. C. (1994) Purification and characterization of a protease actinidin isolated from Cheju kiwifruit. Korean $J$. Food Nutr. 7, 87-94.

6. Choe, I. S. and Park, Y. J. (1996) A study on the utilization as meat tenderizer from Korean pear protease. Korean J. Food 
Sci. Ani. Resour. 16, 89-93.

7. Destafanis, G., Brugiapaglia, A., Barge, M. T., and Dal Molin, E. (2008) Relationship between beef consumer tenderness perception and Warner- Braizier shear force. Meat Sci. 78, 153-156

8. Gyeonggi Provincial Government. (2010) Available from: http://www.gg.go.kr/gg5/silkuk/s7/board/detail.do?bbsId= 386\&themeName $=$ myp\&seq $=669459$. Accessed July 2, 2010.

9. Han, S. K. and Chin, K. B. (2004) Study on meat tenderness of a protease extracted from domestic pear. Korean J. Food Sci. Ani. Resour. 24, 326-328.

10. Jang, K. Y. and Kim, H. (2009) Purchasing situations of beef and the level of consumer's satisfaction on Australian beef. Korean J. Intl. Agri. 21, 85-90.

11. Kawk, D. K., Lyu, E. S., Lee. H. S., Hong, W. S., and Jang, H. J. (2007) Foodservice management. Shin Kwang Chul Pan Sa, Seoul, Korea, pp.19-20 (in Korean).

12. Kim, C. J., Chae, Y. C., and Lee, E. S. (2001) Changes of physico-chemical properties of beef tenderloin steak by cooking methods. Korean J. Food Sci. Ani. Resour. 21, 314322.

13. Kim, E. M., Choe, I. S., and Hwang, S. G. (2003) Effects of singular manner or mixed type treatment of proteases isolated from pear, pineapple and kiwifruit on actomyosin degradation. Korean J. Food Sci. Ani. Resour. 23, 193-199.

14. Kim, G. J., Byun, G. I., and Jung, W. S. (2009) A study on the potential effects of consumer preference for beef and involvement in the attributes of the beef selection on consumers' purchase intentions. Korean J. Culinary Res. 15, 286-298.

15. Kim, K. J. and Lee, Y. B. (1995) Effect of ginger rhizome extract on tenderness and shelf life of precooked lean beef. Korean J. Soc. Food Sci. 11, 119-121.

16. Kim, K. J., Min, J. S., Lee, S. O., Jang, A., Cheon, Y. H., and Lee, M. (2003) Effect of natural tenderizers of phosphates on quality improvement of the low-grade seasoned Hanwoo ribs. J. Anim. Sci. Technol. 45, 309-318.

17. Kim, M. J. (2008) A survey of dining-out behaviors and menu preferences of university students in the Seoul area. Korean J. Food Cookery Sci. 24, 525-535.

18. Kim, S. H., Cha, M. H., and Kim, Y. K. (2006) High school students' preferences and food intake on menu items offered by school foodservice in Daegu. J. Korean Soc. Food Sci. Nutr. 35, 945-954.

19. Lawrie, R. A. and Ledward, D. A. (2006) Lawrie's meat science. 7th ed, Woodhead Publishing, Cambridge, England.

20. Lee, E. J., Oh, S. W., Lee, N. H., Kim, Y. H., Lee, D. U., Yamamoto, K., and Kim, Y. J. (2009) Application of a kiwifruit (Actinidia chinensis) to improve the textural quality on beef bulgogi treated with hydrostatic pressure. Korean $J$. Food Sci. Ani. Resour. 29, 317-324.

21. Lee, J. M., Kim, T. W., Kim, J. H., Cho, S. H., Seong, P. N.,
Jung, M. O., Cho, Y. M., Park, B. Y., and Kim, D. H. (2009) Comparison of chemical, physical and sensory traits of longissimus lumborum Hanwoo beef and Australian wagyu beef. Korean J. Food Sci. Ani. Resour. 29, 91-98.

22. Lee, K. H. and Park, E. S. (2010) School food service satisfaction and menu preferences of high school studentsfocused on Iksan, Cheonbuk. Korean J. Commun. Nutr. 15, 108-123.

23. Lee, S. A., Song, Y. S., Cho, J. W., Lee, J. H., and Cho, J. S. (2001) Effect of the Sarcodon aspratus on the physiochemical and sensory properties of cooked beef. Kor. Soc. Food Sci. Nutr. 30, 266-272.

24. Ministry of Education, Science and Technology. (2010) The present status school foodservice in 2009. Available from: http://www.mest.go.kr/me_kor/inform/info_data/school/ 1262543_10821.html. Accessed July 2, 2010.

25. Oh, Y. M., Kim, M. H., and Sung, C. J. (2006) The study of satisfaction, meal preference and improvement on school lunch program of middle school boys and girls in Jeonju. $J$. Korean Diet Assoc. 12, 358-368.

26. Park, C. J. and Park, C. S. (2001) Quality characteristics of pork by cooking conditions. Korean J. Soc. Food Cookery Sci. 17, 490-496.

27. Park, S. H. and Kim, M. J. (2008) Acceptance and preference of vegetables in menus for middle school students. J. Korean Soc. Food Sci. Nutr. 37, 1660-1666.

28. Park, S. W. and Kwon, S. K. (1998) Sensory characteristics and tenderness of boiled beef by addition of the barks (Morus alba Linne). Korean J. Food Nutr. 11, 580-584.

29. Serra, X., Guerrero, L., Guardia, M. D., Gil, M., Sanude, C., Panca, B., Campo, M. M., Olleta, J. L., Garcia-Cachan, M. D., Piedrafita, J., and Oliver, M. A. (2008) Eating quality of young bulls from three Spanish beef breed-production systems and its relationships with chemical and instrumental meat quality. Meat Sci. 79, 98-104.

30. Suh, H. J., Chung, S. H., Choi, Y. M., and Cho, W. D. (1998) Protease activities in tenderizing effect of vegetables used as cooking material. Korean J. Food Sci. Technol. 30, 883-887.

31. Yamaguchi, T., Yamashita, Y., Takeda, I., and Hirashi, K. (1982) Proteolytic enzymes in green asparagus, kiwifruit and miut: Occurrence and partial characterization. Agric. Biol. Chem. 46, 1983-1986.

32. Yoon, G. S. and Woo, J. W. (1999) Preferences of meat food and its related factor in Koreans. Korean J. Soc. Food Sci. 15, 524-532.

33. Yun, S. J. and Jang, M. S. (1997) Effect of extract or crude enzyme extracted from the fruit of paper mulberry (Broussonetia kazinoki Siebold) on tenderness and palatability of jangchorim. Korean J. Soc. Food. Sci. 13, 617-622.

$\overline{\text { (Received 2010.7.19/Revised 2010.7.26/Accepted 2010.7.28) }}$ 